\title{
Evidence for a Secular Trend in Age of Menarche
}

\section{Citation}

Wyshak, Grace, and Rose E. Frisch. 1982. "Evidence for a Secular Trend in Age of Menarche." N Engl J Med 306 (17) (April 29): 1033-1035. doi:10.1056/nejm198204293061707.

\section{Published Version}

doi:10.1056/NEJM198204293061707

\section{Permanent link}

http://nrs.harvard.edu/urn-3:HUL.InstRepos:16953385

\section{Terms of Use}

This article was downloaded from Harvard University's DASH repository, and is made available under the terms and conditions applicable to Other Posted Material, as set forth at http:// nrs.harvard.edu/urn-3:HUL.InstRepos:dash.current.terms-of-use\#LAA

\section{Share Your Story}

The Harvard community has made this article openly available.

Please share how this access benefits you. Submit a story.

\section{Accessibility}


Table 1. Diagnoses in 30 Patients with Transient Proteinuria and Incidence Rates of Proteinuria.

\begin{tabular}{lccc}
\hline Diagnosis & $\begin{array}{c}\text { No. of Patients } \\
\text { With Transient } \\
\text { Proteinuria }\end{array}$ & $\begin{array}{c}\text { Total No. } \\
\text { OF Patients }\end{array}$ & $\begin{array}{c}\text { Incidence of } \\
\text { Proteinuria }\end{array}$ \\
& 10 & 42 & $\%$ \\
Congestive heart failure & 5 & 13 & 24 \\
$\begin{array}{l}\text { Seizures } \\
\text { Pneumonia }\end{array}$ & 4 & 11 & 38 \\
$\begin{array}{l}\text { Infection, other sites } \\
\text { Chronic obstructive } \\
\text { pulmonary disease }\end{array}$ & 3 & - & - \\
Miscellaneous & 2 & - & - \\
Fever * & 6 & 49 & - \\
\hline
\end{tabular}

* Fever is considered independently, and these patients may have other diagnoses.

proteinuria. Other possible mechanisms include adrenergic discharge or fever accompanying the seizure. Once again, the proteinuria accompanying seizures is selective for albumin, suggesting a glomerular origin.

Our experience with febrile proteinuria (which occurred in 16 per cent of our febrile patients) suggests that this disorder may occur more frequently than Marks et al. have reported (5.6 per cent of febrile patients). ${ }^{2}$ In both series, respiratory infections were the most frequent causes of the fever ( 50 per cent in our current study and 30 per cent in that of Marks et al.). The mechanism may be the fever itself ${ }^{5}$ or an immunologic mechanism in which antigen-antibody complexes, stimulated by infection, are temporarily deposited on the epithelial side of the glomerular membrane. ${ }^{6}$ Although albumin was the predominant urinary protein, three of our patients with pneumonia also had increased alpha globulin, which may represent the orosomucoid seen universally in Jensen and Henriksen's patients. ${ }^{6}$ In their study, increased excretion was thought to have a prerenal basis, since the serum concentration of the protein was also elevated, probably as an acute-phase reactant.

The remaining cases of transient proteinuria have little in common other than the physiologic stress of the acute illness that prompted admission and the accompanying psychological stress. Presumably, these stresses affect all patients with acute medical illnesses, so we are at a loss to explain why only some patients had transient albuminuria.

On the basis of these findings, the clinician who notes proteinuria with normal renal function in patients with congestive heart failure, seizures, or febrile illnesses need not begin diagnostic work-up for proteinuria. A repeat urinalysis 10 days after admission should confirm the diagnosis of transient proteinuria.

We are indebted to Serafino Garella, M.D., Horace Martin, M.D., Ph.D., Pat Harrison, and Richard Matarese, M.D., for their assistance.

\section{REFERENCES}

1. Levinsky NG. The interpretation of proteinuria and the urinary sediment. DM. March 1967:1-40.

2. Marks MI, McLaine PN, Drummond KN. Proteinuria in children with febrile illnesses. Arch Dis Child. 1970; 45:250-3.

3. Pesce MA, Strande CS. A new micromethod for determination of protein in cerebrospinal fluid and urine. Clin Chem. 1973; 19:1265-7.

4. Robinson RR, Dennis VW. Mechanisms and clinical significance of proteinuria in asymptomatic patients. Contrib Nephrol. 1978; 14:97-110.

5. Welty JW. Febrile albuminuria. Am J Med Sci. 1937; 194:70-4.

6. Jensen $\mathbf{H}$, Henriksen $\mathrm{K}$. Proteinuria in non-renal infectious diseases. Acta Med Scand. 1974; 196:75-82.

\section{EVIDENCE FOR A SECULAR TREND IN AGE OF MENARCHE}

\author{
Grace Wyshak, Ph.D., and Rose E. Frisch, Ph.D.
}

$\mathrm{W}$

E present data documenting a secular trend toward an earlier age of menarche in Europe and the United States in the past century. There has been recent controversy on whether such a change has taken place. ${ }^{1,2}$ We have reviewed 218 reports on age of menarche in Europe from 1795 to 1981, covering 220,037 individuals. $^{3-6}$ The historical European data are mainly from Backman's extensive collation. ${ }^{3}$

Figure 1 and Table 1 show that in Europe the age of menarche has become earlier by two to three months per decade in the past century and a half. The greatest rate of decline, 3.2 months per decade, has been observed in the Scandinavian countries. ${ }^{3-5}$ The smallest rate of decline, 1.1 month per decade, has been observed in France.

Although the European historical data are undoubtedly variable in quality and method of collection, the overall trend is statistically significant (Table 1) and consistent with the well-documented acceleration in height and weight of girls and boys in the past century. ${ }^{3-5,7}$ When the rate of growth levels off with optimal conditions, the age of menarche also levels off. ${ }^{5,8}$ Also consistent with the data on growth is the disappearance of rural-urban differences in age of menarche and of differences associated with social class, occurring as socioeconomic conditions became more equitable in 20th-century populations. ${ }^{4,5}$

The data from the United States also indicate a secular trend in age of menarche of about two months per decade in the past century. ${ }^{7}$ The average age of menarche was 14.75 years in Bowditch's pioneer study in $1877,{ }^{9}$ about 14 years at the turn of the century, and 12.8 years in $19477^{7,8,10}$ The downward trend apparently leveled off at about 12.8 years; recent ages of menarche are still the same ${ }^{11-13}$ (Fig. 1). Between 1900 and 1945 in the United States, a downward trend

From the Department of Social Medicine and Health Policy, Harvard Medical School, Boston, and the Harvard Center for Population Studies, Cambridge, Mass. Address reprint requests to Dr. Wyshak at Harvard Center for Population Studies, 9 Bow St., Cambridge, MA 02138. 


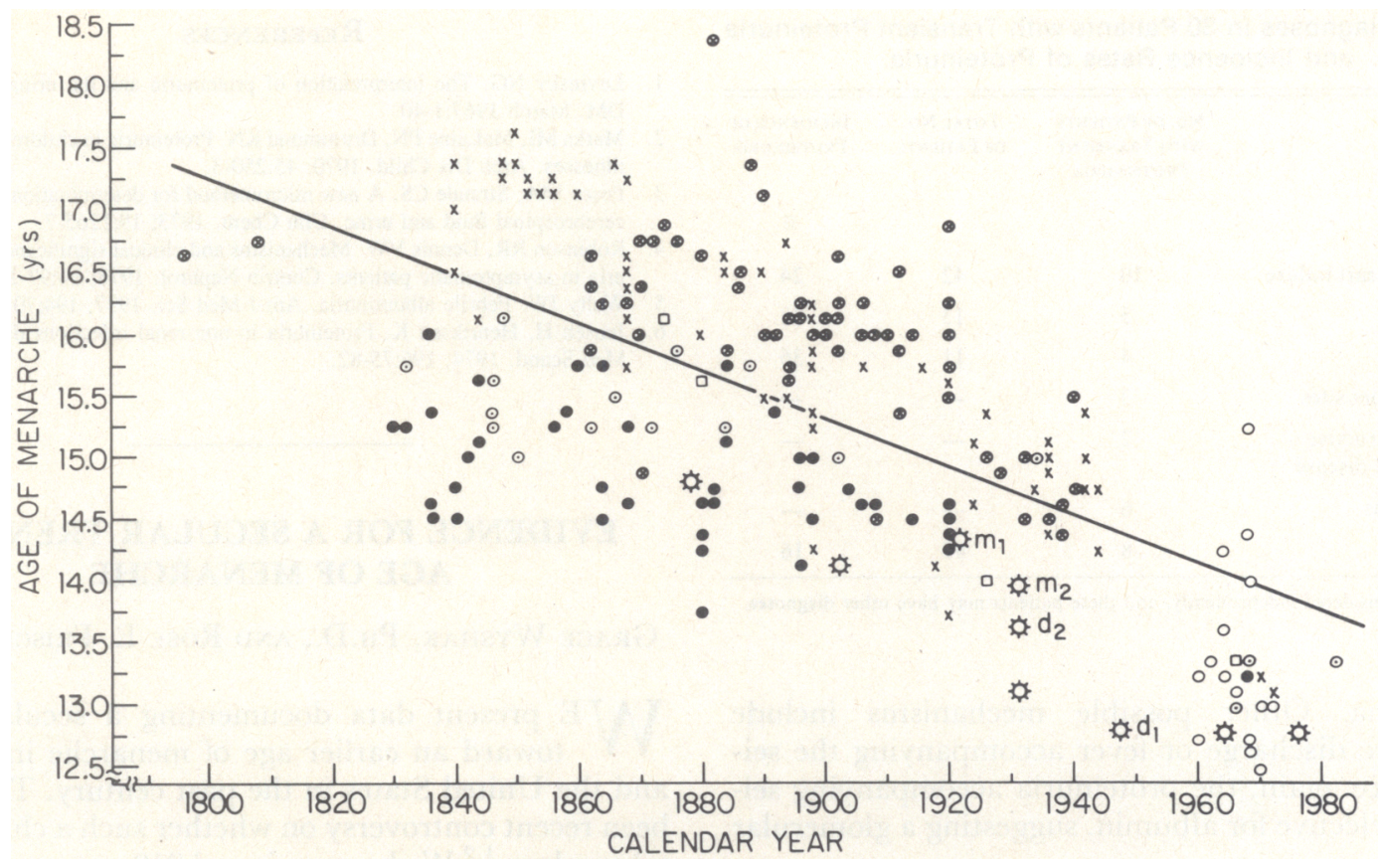

Figure 1. Mean or Median Age of Menarche as a Function of Calendar Year from 1790 to 1980.

The symbols refer to England $(\odot)$; France $(\Theta)$; Germany $(\otimes)$; Holland $(\square)$; Scandinavia ( $x$ ) (Denmark, Finland, Norway, and Sweden); Belgium, Czechoslovakia, Hungary, Italy, Poland (rural), Romania (urban and rural), Russia (15.2 years at an altitude of $2500 \mathrm{~m}$ and 14.4 years at $700 \mathrm{~m}$ ), Spain, and Switzerland (all labeled O); and the United States ( $\$$, data not included in the regression line). Twentyseven points for Europe were identical and do not appear on the graph. The regression line cannot, of course, be extended indefinitely. The age of menarche has already leveled off in some European countries, ${ }^{5}$ as it has in the United States (see text).

Sources of data on the United States are Englemann ${ }^{19}$ for 1900 ; Damon et al. ${ }^{10}$ for mothers $\left(m_{1}\right)$ in 1920 and daughters $\left(d_{1}\right)$ in 1947 ; Gould and Gould ${ }^{20}$ for mothers $\left(m_{2}\right)$ and daughters $\left(d_{2}\right)$ in 1932; Boas, cited in Zacharias and Wurtman, ${ }^{13}$ for private-school students in 1932; MacMahon ${ }^{11}$ for 1965; and Zacharias et al. ${ }^{12}$ for 1976.

in age of menarche of about three months per decade occurred in mothers of twins or of singletons, correlating with a more rapid gain in body weight (Wyshak G: unpublished data).

The findings in Europe and the United States are consistent with the fact that menarche is delayed by undernutrition ${ }^{5,8,14}$ and strenuous physical exercise. ${ }^{15-17}$ For example, the age of menarche is still relatively late, about 15 years, among poor girls in developing countries ${ }^{5,18}$ and among dancers ${ }^{15,16}$ and athletes ${ }^{17}$ in affluent countries. Menarche may also be delayed in girls living at high altitudes, in association

Table 1. Secular Trend in Age of Menarche in Europe.

\begin{tabular}{|c|c|c|c|c|c|c|}
\hline Country & $\begin{array}{l}\text { No. of } \\
\text { SAMPLES } \\
\text { (No. OF } \\
\text { INDIVIDUALS) }\end{array}$ & $\begin{array}{c}\text { TIME } \\
\text { PERIOD }\end{array}$ & REgRESSION EQUATION * & $\begin{array}{c}\text { DeCLINE } \\
\text { IN } \\
\text { MoNTHS/ } \\
\text { DeCADE }\end{array}$ & $\begin{array}{l}\text { CoRrelation } \\
\text { COEFFICIENT } \\
(r)\end{array}$ & P VAlue \\
\hline Europe $†$ & $\begin{array}{c}218 \\
(220,037)\end{array}$ & $1795-1981$ & $Y=51.74-0.0192( \pm 0.0015) X$ & -2.3 & 0.658 & $<0.001$ \\
\hline $\begin{array}{l}\text { Europe excluding } \\
\text { France }\end{array}$ & $\begin{array}{c}170 \\
(192,178)\end{array}$ & $1795-1981$ & $Y=62.38-0.0246( \pm 0.0014) X$ & -3.0 & 0.801 & $<0.001$ \\
\hline Scandinavia & $\begin{array}{c}68 \\
(83,957)\end{array}$ & $1839-1972$ & $Y=66.88-0.0270( \pm 0.0018) X$ & -3.2 & 0.879 & $<0.001$ \\
\hline Germany & $\begin{array}{c}63 \\
(76,800)\end{array}$ & $1795-1939$ & $Y=48.65-0.0172( \pm 0.0028) X$ & -2.0 & 0.619 & $<0.001$ \\
\hline France & $\begin{array}{c}47 \\
(26,959)\end{array}$ & $1830-1967$ & $Y=32.50-0.0094( \pm 0.0020) X$ & -1.1 & 0.570 & $<0.001$ \\
\hline England $\ddagger$ & $\begin{array}{c}19 \\
(29,427)\end{array}$ & $1832-1981$ & $Y=45.54-0.0162( \pm 0.0022) X$ & -1.9 & 0.870 & $<0.001$ \\
\hline
\end{tabular}

* $\mathrm{Y}$ denotes age of menarche, and $\mathrm{X}$ calendar year.

†Historical data are from Backman, ${ }^{3}$ and data on Holland and England (1981) ${ }^{6}$ are included. Recent ages of menarche for Belgium, Czechoslovakia, Hungary, Italy, Poland, Romania, Russia, Spain, and Yugoslavia (symbol $O$ in Figure 1), are from Eveleth and Tanner ${ }^{5}$ (no numbers given). If the 17 samples from these nine countries are omitted from the total for Europe, the regression equation is: $Y=45.01-0.0156( \pm 0.0017) X$; the decline is 1.9 months per decade; $r=0.544 ; P<0.001$.

łIncludes 1981 age of menarche from reference 6. 
with slower rates of physical growth ${ }^{5,8}$ (Fig. 1). In Bangladesh, unfortunately, there has recently been a trend toward a later age of menarche accompanying adverse economic conditions and a deterioration in the diet. ${ }^{18}$ In evaluating the age of menarche of a population or an individual girl, it is important to consider these environmental factors.

\section{REFERENCES}

1. Bullough VL. Age at menarche: a misunderstanding. Science. 1981; 213: 365-6.

2. Tanner JM. Menarcheal age. Science. 1981; 214:604.

3. Backman G. Die beschleunigte Entwicklung der Jugend: verfrühte Menarche verspätete Menopause, verlängerte Lebensdauer. Acta Anat (Basel). 1948; 4:421-80.

4. Kiil V. Stature and growth of Norwegian men during the past 200 years. Skr Norske VidenskAkad. 1939; 2:1-176.

5. Eveleth PB, Tanner JM. Worldwide variation in human growth. Cambridge: Cambridge University Press, 1976:213-9, 260-1

6. Billewicz WZ, Fellowes HM, Thomson AM. Menarche in Newcastle upon Tyne girls. Ann Hum Biol. 1981; 8:313-20.

7. Cone TE Jr. Physical growth and maturation. In: Cooke RE, Levin S, eds. The biological basis of pediatric practice. New York: McGraw-Hill, 1968:1338-47.

8. Frisch RE, Revelle R. Height and weight at menarche and a hypothesis of menarche. Arch Dis Child. 1971; 46:695-701.
9. Bowditch HP. Eighth annual report. Boston, Mass.: Massachusetts State Board of Health, 1877.

10. Damon A, Damon ST, Reed RB, Valadian I. Age at menarche of mothers and daughters with a note on accuracy of recall. Hum Biol. 1969; 41:16175.

11. MacMahon B. Age at menarche: United States, 1973. Rockville, Md.: National Center for Health Statistics, 1974. (DHEW publication no (HRA)74-1615).

12. Zacharias L, Rand WM, Wurtman RJ. A prospective study of sexual development and growth in American girls: the statistics of menarche. Obste Gynecol Surv. 1976; 31:325-37.

13. Zacharias L, Wurtman RJ. Age at menarche: genetic and environmental influences. N Engl J Med. 1969; 280:868-75.

14. Frisch RE, McArthur JW. Menstrual cycles: fatness as a determinant of minimum weight for height necessary for their maintenance or onset. Science. 1974; 185:949-51.

15. Frisch RE, Wyshak G, Vincent $L$. Delayed menarche and amenorrhea in ballet dancers. N Engl J Med. 1980; 303:17-9.

16. Warren MP. The effects of exercise on pubertal progression and reproductive function in girls. J Clin Endocrinol Metab. 1980; 51:1150 7.

17. Frisch RE, von Gotz-Welbergen AV, McArthur JW, et al. Delayed menarche and amenorrhea of college athletes in relation to age of onset of training. JAMA. 1981; 246:1559-63.

18. Chowdhury AKMA, Huffman SL, Curlin GT. Malnutrition, menarche, and marriage in rural Bangladesh. Soc Biol. 1978; 24:316-25.

19. Englemann GJ. Age of first menstruation on the North American continent. NY Med J. 1902; 75:221-8, 270-6.

20. Gould HN, Gould MR. Age of first menstruation in mothers and daughters. JAMA. 1932; 98:1349-52.

\section{CASE RECORDS}

\section{OF THE}

\section{MASSACHUSETTS GENERAL HOSPITAL}

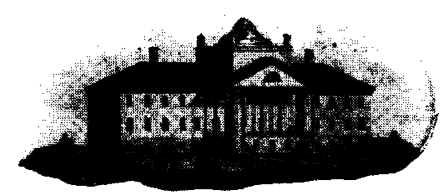

\section{Weekly Clinicopathological Exercises}

\author{
FOUNDED BY RICHARD C. GABOT \\ Robert E. Scully, M.D., Editor \\ Eugene J. Mark, M.D., Associate Editor \\ BetTy U. McNeely, Assistant Editor
}

\section{CASE 17-1982}

\section{Presentation of Case}

A 77-year-old man was admitted to the hospital because of fever and subcutaneous masses.

He was well until three months previously, when a dry cough developed. Two months before admission the temperature rose to $38.9^{\circ} \mathrm{C}$, accompanied by chills, pleuritic pain, and anorexia. Erythromycin was administered for two weeks, without improvement. He was admitted to another hospital. X-ray films of the chest showed small bilateral pleural effusions. A tuberculin skin test was markedly positive. Repeated blood cultures and cultures of urine and pleural fluid yielded no microorganisms. Cytologic examination of the pleural fluid and microscopical examination of a pleural-biopsy specimen were negative; no acid-fast bacilli were observed. An intravenous urographic examination disclosed a large, irregular mass invading the base of the bladder, especially on the right side; there was slight dilatation of both ureters, and a small diverticulum projected from the right wall of the bladder; the upper urinary tracts and kidneys appeared normal. A computed tomographic (CT) scan of the abdomen showed a solid mass involving the right posterolateral portion of the bladder wall and considerable enlargement of the prostate gland; a diverticulum of the bladder was observed on the right side; the pancreas and retroperitoneum appeared normal; there was no evidence of an abscess or lymphadenopathy. The fever subsided, and the pleural effusions resolved. The patient left the hospital before a barium-enema examination and upper gastrointestinal series were accomplished. Soon after discharge fever recurred. One or two weeks before entry tender masses appeared in the left thigh and the right gluteal region. One week before admission he was first seen at this hospital. An intravenous urographic examination disclosed probable calcification in the retropubic area and degenerative changes in the lower lumbar spine; there was prompt symmetric opacification of the collecting systems, and nephrotomographic examination disclosed normal renal parenchyma and outlines; the ureters appeared normal; the bladder was trabeculated, with a diverticulum on its right side and an irregular impression on the bladder base; there was a moderate postvoiding residuum of urine. On follow-up examination one week later fever persisted, and the patient was admitted to this hospital. 